Article

\title{
Business Incentive to Reduce Food Losses in Japan
}

\author{
Jun Igeta ${ }^{1}$ and Hiroki Nakamura ${ }^{2,3, *}$
}

1 Eight Good, Inc., Tokyo 197-0825, Japan; jun.i@eightgood.com

2 Institute of Social Science, The University of Tokyo, Tokyo 113-0033, Japan

3 Yunus \& Shiiki Social Business Research Center, Kyushu University, Fukuoka 815-0032, Japan

* Correspondence: hnakamu@iss.u-tokyo.ac.jp

check for

updates

Citation: Igeta, J.; Nakamura, H.

Business Incentive to Reduce Food

Losses in Japan. Sustainability 2022,

14, 2266. https://doi.org/10.3390/

su14042266

Academic Editor: Antonio Boggia

Received: 13 December 2021

Accepted: 13 February 2022

Published: 16 February 2022

Publisher's Note: MDPI stays neutral with regard to jurisdictional claims in published maps and institutional affiliations.

Copyright: (C) 2022 by the authors. Licensee MDPI, Basel, Switzerland. This article is an open access article distributed under the terms and conditions of the Creative Commons Attribution (CC BY) license (https:/ / creativecommons.org/licenses/by/ $4.0 /)$.

\begin{abstract}
Although market-based or new business solutions such as food sharing services are important to reduce food wastage, a limited amount of people use sharing economy services, such that real restaurant services are scarce in countries such as Japan. Moreover, while the perspectives of consumer and food wasting behavior in restaurants, doggy bags, and new sharing business applications are important, existing studies related to food loss have not focused on these issues all together in an analytic model. Therefore, this study proposes a new business incentive model to reduce food loss, and we further analyze the feasibility and potential of our proposal by extending the existing basic analytic model. The proposed service is to provide coupons or points in digital applications if customers finish their meal at a restaurant without wasting food; these coupons/points can be used to avail discounts on their future meals. We considered three models of intention to use incentives to reduce food loss and compared new business proposals with the other two incentive services. The results showed that the proposed services are less likely to be used by people who are interested in but do not experience using food sharing services. Nevertheless, the proposed new service has the potential to be used by younger people and people with household incomes ranging from 5 to 10 million yen, indicating that such services have the potential to create a new target group for food loss implementation and a business that encourages a strategy to reduce food loss.
\end{abstract}

Keywords: business incentive; food loss; consumption stage; Japan

\section{Introduction}

In recent years, technological innovations have made our lives more comfortable. However, despite this, we continue to face various complex social problems, which have attracted international attention. In 2015, the United Nations set sustainable development goals (SDGs) to address social problems such as food loss and avoid wastage of food.

FUSIONS [1] listed various definitions related to food loss and waste, whereas the Food and Agriculture Organization of the United Nations (FAO) [2] has defined that food losses "refer to the decrease in edible food mass throughout the part of the supply chain that specifically leads to edible food for human consumption and occurs at production, postharvest and processing stages in the food supply chain". FAO [2] noted that "food losses occurring at the end of the food chain (retail and final consumption) are instead called 'food wastage', which relates to the behavior of retailers and consumers".

Studies on food loss and wastage have primarily focused on improving food security by saving food and ensuring the efficient use of resources [3]. Gustavson et al. [4] estimated that one-third of the global food production is either lost or wasted; some studies, such as Neff et al. [5] and Qi and Roe [6] indicated that consumers hesitate to consume food items that are past their prime state and prefer fresh food to reduce health risks; therefore, food losses and waste from private households account for a major share of total food loss and waste, especially in developed countries. Moreover, restaurants and food services account for a significant proportion of food wastage and have been identified as an important unsustainability hotspot [7-10]. 
Although little attention has been paid to the possible sharing of consumer-side food surplus [11], recent growing concerns about food losses and wastage and the rise of emerging information and communication technologies (such as web platforms and mobile applications) have enabled the rise of local initiatives that collect, manage, and share food surplus [12]. According to Koester et al. [3], the value of food loss and wastage does not include all the costs and risks associated with reducing food loss and wastage, such that the value of the reduction in food loss and wastage must be evaluated using prices, production costs, or opportunity costs. Richards and Hamilton [13] insisted that commercial peer-topeer mutualization systems represent a potentially important market-based solution for a more efficient allocation of food at higher levels of the food system by stimulating price realization for edible products. Therefore, they investigated the potential for the systems, or sharing economy firms, to emerge as market platforms for the exchange of surplus food.

Although market-based or new business solutions such as food sharing services to reduce food wastage are important, a limited number of people use sharing economy services in countries such as Japan [14] and real services in restaurants or food services are scarce.

This study aims to propose a new business incentive model to reduce food loss, especially in restaurants, and analyzes the feasibility, future potential, and effect of this model by assessing consumer awareness of incentives and food loss via online and smartphone surveys based on, and in comparison with, existing analytical models such as consumer models and sharing service models.

\section{Literature Review}

\subsection{Process and Place of Food Loss Occurrence}

Approximately four billion tons of food is produced annually for human consumption worldwide, with an estimated 1.3 billion tons of food lost annually [2]. This means that approximately one-third of the food produced is discarded. The amount of food lost at each stage of the food supply chain varies depending on the average country income, and a substantial proportion of food is wasted during the consumption stage in middle- and high-income countries. One of the reasons for this is that food loss does not affect the survival of the people in these countries because the food available to them is abundant and easily accessible.

In developed economies in Asia, considerable amounts of food are wasted, particularly at the consumption stage. This is likely due to the same reason as that in middle- and highincome countries. In contrast, in Japan, an excessive focus on food freshness is considered the primary factor leading to food loss. In low-income countries, food loss often occurs during the early or middle stages, and only a small amount is wasted at the consumption stage. Although people in these countries consume the major proportion of food they obtain, a large amount is still wasted owing to insufficient policies and a lack of sanitation controls.

Food loss occurs at various stages of the food supply chain. Although several categories are used to indicate food loss, this study classifies the losses into five stages: production, storage, processing, distribution, and consumption, based on the study by FAO [2]. Food loss closer to the production stage is considered to be in the early stages, whereas when it is closer to consumption, it is considered to be in the late stages or the end phase.

In particular, restaurants and food services account for a significant proportion of food wastage and have been identified as an important unsustainability hotspot [7-10] because approximately $20 \%$ of all food handled and prepared in the restaurant and food service sector is wasted [15]. For instance, plate waste such as in all-you-can-eat facilities is considered one of the major issues of food wastage in restaurants, and prevention is most important at the end of the value chain, as in restaurants $[7,8,16,17]$. However, there is limited scientific research testing practical interventions to prevent the wastage of food in restaurants and food services $[18,19]$. 
In Japan, the Ministry of Agriculture, Forestry, and Fisheries initiated statistical research on food loss and waste from households and businesses [20]. Food loss and waste reduction have emerged as key issues for sustainability in Japan, and the Food Loss Reduction Promotion Act was enacted in October 2019. Although concerns about food losses and waste have recently risen in Japan, studies on practical interventions to prevent food wastage and business models that enable the reduction in food losses and waste at restaurants are lacking.

\subsection{Sharing Services to Reduce Food Losses and Users' Motivation}

Sharing services are used as business models for businesses that rent, trade, or share unutilized assets between service providers and consumers using the Internet. The recent growth of such businesses around the world has been led by technological development, an increase in environmental awareness, a change in attitudes toward product ownership, and demand for social networks [21-31].

These businesses enable people to use goods and services sustainably by sharing services rather than acquiring and consuming them individually [32,33]. Food sharing services include shared food consumption, redistribution of foods, shared spaces for growing, preparing, cooking, and eating; sharing of gardening tools; shared interests, skills, and knowledge of foods [34]. Various food sharing services, including food donation, have recently been increasing $[11,35,36]$. However, some empirical studies have indicated that the motivation of consumers to participate in and use food sharing platforms is driven more by economic reasons than environmental reasons [37].

Sharing services should be examined from both economic, environmental, and social perspectives. Böcker and Meelen [22] provide a comprehensive understanding of the incentives for using sharing services through a sustainability approach, taking into consideration the economic, environmental, and social motivations; Ozanne and Ballantine [38] indicated that the motivation to participate in a sharing economy could be driven by social aspects. The sharing economy is thought to be a new paradigm that has significant potential to change the social system and achieve the UN SDGs $[39,40]$.

Although the efficient use of resources is an important factor for sharing services from the perspective of sustainability, people use these services for other reasons, including financial reasons [32,41,42]. Hamari et al. [43] analyzed the motivations for people to share services and found that the motivation to use sharing services came from enjoyment of the activity, economic and financial gains, and sustainability. More importantly, they reported that sustainability may only motivate those individuals who consider the environmental impact of these services to be important.

Hawlitschek et al. [44] reviewed studies on consumer motivations for using sharing services and identified that "financial benefits," "trust in other users," "modern lifestyle," "effort expectancy," and "ecological sustainability" were the five most important motivating factors.

Few studies have investigated the relationship between food loss and waste and the use of sharing services [11,45]. Morone et al. [11] performed a statistical analysis to assess the effectiveness of food sharing services to reduce food loss and waste, and the results showed that the introduction of food sharing services by households does not automatically translate into reduced wastage of food. Makov et al. [45] found that these services can be a strong platform for improving resource efficiency and reducing food losses and waste, especially from an environmental assessment perspective.

Although quantitative research is rare, Schanes and Stagl [12] quantitatively analyzed the motivation of people to use food sharing services in Austria. They reported that users of food sharing services were motivated by the following: (1) emotions and morality, (2) identity and sense of community, (3) reward, (4) social influence, and (5) instrumentality. 


\subsection{Theoretical Background and the Research Gap}

There has been a growing interest in establishing food loss prevention programs worldwide, and the consumption level has the highest potential for prevention $[16,46,47]$. Existing research related to insights into the influential factors of food consumption behavior at the household level is mostly based on the theory of consumer behavior or planned behavior $[46,47]$. Consumer behavior is interdisciplinary and includes various approaches developed by diverse disciplines [14]. Ajzen's theory of planned behavior [48,49] is one of the most widely used theoretical models and is frequently used to predict many foodrelated behaviors $[47,50]$. Previous studies $[46,51-53]$ used the theory of planned behavior to explain food wastage behaviors.

In the theory of planned behavior, "intentions" are the main determinants of behaviors, and intentions are predicted by the "attitude" toward the behavior, "perceived behavioral control" over the behavior, and "subjective norms" [54]. Barone et al. [54] extended this theory and found that the intention to reduce food wastage is predicted by attitudes and subjective norms individuals hold toward food wastage reduction; in contrast, individual perceptions of the level of control over the amount of food wasted do not seem to affect the intention to reduce food wastage. Additionally, the results show that concerns over possible health risks and a healthy diet significantly affect the intention to reduce food wastage [54].

According to Attiq et al. [55], the theory of planned behavior does not offer support in explaining the emotions related to food wastage, as suggested by the literature, such as Russell et al. [53] and Filimonau et al. [56]. Scholars have thus emphasized the need to explore other suitable theoretical approaches, such as the theory of interpersonal behavior, the comprehensive model of environmental psychology, and social practice theory [12,53,55]. Attiq et al. [55] used the integration model of the theory of planned behavior and a comprehensive model of environmental psychology to explain food wastage reduction behavior in household consumers. Their results showed that emotional (anticipated guilt), social (sense of community), and cognitive factors (awareness of consequences and environmental knowledge) were positively associated with food wastage reduction behavior [55].

While Coşkun and Yetkin Özbük [57] also extended the theory of planned behavior for their research, they insisted that researchers have not treated consumer food wastage behavior in restaurants in sufficient detail, although consumer food wastage during the consumption stage is usually generated in different settings, such as at home or out of home. The results of their study show that the extended model is useful in predicting consumer food wastage behavior in restaurants, and attitudes toward food wastage, perceived behavioral control, and price consciousness positively affected intention to reduce food wastage [57].

Regarding consumer food wastage behavior in restaurants, a recent study by van Herpen et al. [58] focused on doggy bags as a potential solution to reduce wastage [59] and indicated that existing social norms in many countries and feelings of shame currently inhibit consumers from using doggy bags. Their research examined whether switching to an opt-out system, whereby consumers are offered a doggy bag by default, can decrease feelings of shame and positively affect doggy bag uptake; the results showed that it is possible to overcome feelings of shame and motivate consumers to act sustainably [58].

According to Sato et al. [60], the main reasons for the wastage of food in Japanese restaurants are leftovers and overstocking, and there has been insufficient research on food loss reduction as there are many different types of food restaurants. Although some restaurants in Japan try to reduce food loss by offering doggy bags as a means for consumers to take leftover food home, it is difficult to accept doggy bags in Japan [60]. For instance, some consumers insist that they end up discarding them if they take the leftover food home, while others have more interest in using the food share application for unsold foods as a tool to help reduce food wastage [60], although only a few people use sharing economy services in countries such as Japan [14]. Although real services in restaurants to reduce food loss are scarce, there are discount measures for fresh or instant food sold in Japanese 
supermarkets or food stores, such as "discount cut (waribiki)" or "half price (hangaku)." These measures have been implemented for many years to reduce food loss and avoid food wastage.

While the viewpoints of consumer theory, food wastage behavior in restaurants, doggy bags, and new sharing business applications are important, existing studies related to food loss have not focused on these issues all together in the analytic model. Therefore, this study proposes a new business incentive model to reduce food loss, especially in restaurants, and analyzes the feasibility, future potential, and effect of the model by assessing consumer awareness of incentives and food loss via online and smartphone surveys based on existing analytical models such as consumer models and sharing service models.

\section{Services Available to Reduce Food Losses}

Before proposing a new business incentive model to reduce food loss, especially in restaurants, and analyzing the feasibility, future potential, and effect of our model, this section briefly summarizes examples of food loss reduction efforts in Japan and around the world. In general, projects or businesses that reduce food loss can be categorized into six groups: (1) distribution of discarded food; (2) redistribution of surplus food; (3) restaurants that use waste and surplus ingredients; (4) waste data management and utilization; (5) extension of food expiration date by technology; (6) discount and incentive businesses for loss-reduction actions.

\subsection{Examples of Global Food Loss Reduction Efforts}

Projects or businesses to reduce food loss have been implemented in various countries, as illustrated in Table 1. This suggests that businesses that share food items that are not typically distributed during the production stage or those that redistribute food items that are in excess or are to be discarded after the initial distribution operate differently in various countries.

Table 1. List of worldwide food loss reduction projects by nature of operations.

\begin{tabular}{lcl}
\hline Name & Country & Description \\
\hline $\begin{array}{l}\text { Group 1. Distribution of discarded food } \\
\text { Imperfect Produce }\end{array}$ USA & $\begin{array}{l}\text { Buys out-of-specification vegetables and fruits directly from farms and sells discounted crops for } \\
\text { members to purchase. } \\
\text { Connects food and beverage companies and individuals to farms and allows them to purchase } \\
\text { out-of-specification agricultural products and surpluses. } \\
\text { Full Harvest }\end{array}$ USA & $\begin{array}{l}\text { Designs a mechanism that enables the most effective use of foods suitable for consumption, } \\
\text { introduces stakeholders necessary to this mechanism, and provides consulting services for } \\
\text { operations and monitoring. }\end{array}$ \\
\hline
\end{tabular}

Group 2. Redistribution of surplus food

Copia

USA

Food For All

USA

Community Shop

UK

The Real Junk Food Project

UK

OLIO
This company neatly wraps the leftover food from various company occasions and transports it to nearby nonprofit organizations. The company also provides surplus data to help businesses make improved decisions to avoid producing surplus food.

Food For All is an application (app) that began in Cambridge that allows users to buy unsold restaurant food items at a discounted price. Users can find nearby restaurants that sell unsold food items by logging into the app, and if they find an item they like, they can pay online and then go to the restaurant to pick up the ordered item. The pick-up time is typically right before the restaurant closes, and users can purchase an item at a maximum $50-80 \%$ discount off the original price. Community Shop is the largest surplus food redistribution company in the UK and a supermarket for low-income earners. The company buys items that failed to enter into the mainstream distribution channels due to nearing the expiration date and/or packaging issues for below market price and sells them at a discount of approximately $30 \%$ of the regular price.

This company uses warehouses in the industrial park to sell products that are otherwise going to be discarded. Food is redistributed using partnership networks, such as shared houses, cafes, and schools.

OLIO is a matching service that connects users who wish to give away food with users who wish to receive it. The user uploads images of the food they wish to give away to OLIO and posts the pick-up location, date, and time. Then, users who wish to obtain the food contact the owner for pick up. This service is also currently used in Sweden and the United States. 
Table 1. Cont.

\begin{tabular}{|c|c|c|}
\hline Name & Country & Description \\
\hline SirPlus & Germany & $\begin{array}{l}\text { Originating in Berlin, this is a startup company that only handles food that is to be discarded. It } \\
\text { also entered into a partnership with Metro, a supermarket in Germany, and has begun } \\
\text { crowdfunding. }\end{array}$ \\
\hline ResQ Club & Germany & $\begin{array}{l}\text { This organization is a subsidiary of EatUp } \mathrm{GmbH} \text { that provides an app for food sharing services. } \\
\text { The company provides a service where a store sends a request to post unsold items at restaurants, } \\
\text { grocery stores, cafés, etc., on the app, and then users come to the store to pick up the items. }\end{array}$ \\
\hline Foodsharing & Germany & $\begin{array}{l}\text { This is an internet platform that was launched in } 2011 \text { and is led by Mr. Valentin Thurn, who } \\
\text { produced the documentary film Taste the Waste. The company helps various stakeholders, such as } \\
\text { individuals, retailers, and producers, to share excess food. The company also provides an online } \\
\text { bulletin board and various tools for transmitting the information. }\end{array}$ \\
\hline Too Good to Go & Denmark & $\begin{array}{l}\text { Too Good to Go is a service that allows users to search for restaurants with unsold dishes that are } \\
\text { on the verge of being disposed of and to buy them at low prices. It originated in Denmark and is } \\
\text { now available in six European countries. Currently, the majority of contracts are made with } \\
\text { individual restaurants, and the company is seeking to collaborate with major restaurant companies } \\
\text { with high percentages of food loss. }\end{array}$ \\
\hline WeFood & Denmark & $\begin{array}{l}\text { This is a supermarket that opened in February } 2016 \text { in Copenhagen, the capital of Denmark, and it } \\
\text { specializes in handling expired food. The supermarket sells food items at a } 30-40 \% \text { discount that } \\
\text { can no longer be sold at regular supermarkets. }\end{array}$ \\
\hline Karma & Sweden & $\begin{array}{l}\text { Karma, launched in } 2016 \text { in Sweden, provides a service where users can buy unsold items at low } \\
\text { prices from registered stores. It is currently expanding to London, England and it continues to } \\
\text { rapidly expand the range of its services. }\end{array}$ \\
\hline
\end{tabular}

Group 3. Restaurants that use waste and surplus ingredients

This company receives food items for free that would otherwise be wasted and operates a

$\begin{array}{ll}\text { RESTLOS GLÜCKLICH Gestaurant that creates a menu based on these ingredients. Because the ingredients provided } & \text { Geach time, the restaurant changes its menu frequently depending on the type of ingredients }\end{array}$ received. It also focuses on food education activities and holds workshops during lunch at elementary schools.

Instock is a restaurant that creates a menu of the day using ingredients from contracted shops in

Instock Netherlands the city that it picks up every morning, such as out-of-specification vegetables and bread baked on the previous day.

This is a restaurant that opened in Denmark in 2013, and it serves dishes with ingredients that are

Spisehuset Rub and Stub Denmark supposed to be discarded. This restaurant is a nonprofit organization operated by volunteers, offers a daily special menu and an all-you-can-eat option, and allows customers to take food home.

Group 4. Waste data management and utilization

This is a startup company that provides an app that calculates how much money was wasted on

WINNOW

UK

food and provides advice on how to reduce this wasteful spending. Users record information on the discarded food, the food weight, and the reason for the waste (e.g., letting the food spoil, taking more than needed, burning while cooking, etc.).

FridgeCam is a service that automatically captures images, collects information about food items in the refrigerator every time the door closes, and monitors the remaining food items in the refrigerator based on the image data. It monitors when the food will reach its expiration date and

FridgeCam

UK proposes which food should be purchased again based on the historical data. Users can check and manage the list of food in the refrigerator at any time using the app. The company aims to optimize production by collecting food wastage data for each household and reselling it to food manufacturing companies.

Group 5. Extension of Food Expiration Date by Technology

This is a startup company that aims to maintain the freshness of plant-based fresh products using thin films made from plant epidermis to maintain freshness. Liquids made from lipids contained in

Apeel

USA the skin of the fruit called Edipeel, a degradation inhibitor developed by the company, are placed on the fruit, which can double the expiration date.

FreshPaper

USA FreshPaper refers to reusable paper that suppresses the growth of bacteria or fungi. Food placed on the paper can last two to four times longer than usual.

Group 6. Discount and incentive businesses for loss reduction actions

No Food wastaged Netherlands

This company provides an app that contacts the users and prompts them to purchase food registered by supermarkets and restaurants as being sold at a discount price due to reasons such as an approaching expiration date.

Froodly is an app that connects consumers who wish to buy food at the lowest possible price to food that is nearing its expiration date at retail stores. Users take pictures of food that is nearing its

Froodly Finland expiration date in a supermarket and upload the pictures to the app with the discount. The discount ranges from $30 \%$ to $70 \%$ of the normal price. Users receive 10 credits each time they upload one picture. They can receive a discount on food items or a reward, such as free coffee. Wasteless is a company that has developed the first tracking system, called dynamic pricing, in

Israel which grocery stores use the internet and machine learning technologies to change prices in real time according to the product expiration dates. 
Many of these companies are involved in matching waste and surplus food with consumers; however, businesses that process waste and surplus food and provide it to customers as meals are also included in Group 2. Compared to Groups 1-3, Groups 4-6 utilize technology fully. Since 2018, only a few companies have entered the business field of reducing food loss and wastage, and most of the food loss efforts have been made at the production and distribution stages.

Awareness-raising activities for consumers include disclosing food loss information to increase their awareness, providing useful information to consumers, and recording the volume of wasted food. From case studies in the United Kingdom and the Netherlands, consumer awareness-raising activities have yielded positive results when the activities demand that consumers take action.

\subsection{Examples of Food Loss Reduction Efforts in Japan}

Table 2 presents a summary of the food reduction projects in Japan. Reducing food loss in Japan may be slower than that in the United States and Europe. However, public administrative bodies may have affected the speed of this process. Many projects, especially food sharing projects, which were started in 2018, suggest that there is increasing interest in reducing food loss and wastage in Japan.

Three challenges affect businesses related to food loss reduction. The first challenge is that, as previously noted, food loss in developed countries tends to occur more frequently at the consumption stage, and it cannot be confirmed that these projects reduce food loss at the consumption stage. FAO (2011) stipulates that "food loss reduction at the consumption stage should be achieved through awareness activities"; therefore, Japan and other countries are encouraging consumers to take action without having businesses or public administrative bodies to intervene in consumer decision making.

The second issue is the limited number of locations where food sharing can occur. In Japan, services such as Reduce GO and TABETE have been launched in the central part of Tokyo and certain areas in Osaka. However, these services cannot be provided in certain areas because of the lack of sufficient value to users, which typically occurs in areas with many restaurants, and restaurants can only expect sufficient results in areas with a high population.

The third issue is uncertainty regarding whether the current mainstream waste and surplus food redistribution business model leads to a reduction in fundamental food loss. Even if businesses promote the sale of food that would otherwise be wasted, there remains the possibility that food loss increases at the consumption stage. From a macro perspective, this can also lead to price competition, which may cause the amount of food lost by a certain business to decrease, while that of another business increases.

Table 2. List of Food Loss Reduction Projects in Japan by Nature of Operation.

\begin{tabular}{|c|c|c|}
\hline Name & Provider & Description \\
\hline \multicolumn{3}{|c|}{ Group 1. Distribution of waste food } \\
\hline SEND & PLANET TABLE Inc. & $\begin{array}{l}\text { SEND is a service that connects producers and buyers, providing a hub to ensure that food } \\
\text { production and distribution can be sustained. The company aims to achieve a society in which } \\
\text { production leads to sales by matching a production area with a city. }\end{array}$ \\
\hline VEGHEET & Isle Co., Ltd. & $\begin{array}{l}\text { VEGHEET is a new food item made exclusively with out-of-specification vegetables by } \\
\text { processing pasted vegetables into sheets using a seaweed dryer. In addition to carrot- and } \\
\text { radish-based sheets, sheets made from pumpkins, tomatoes, and spinach are also available. }\end{array}$ \\
\hline Share Shima & ICS-net Inc. & $\begin{array}{l}\text { Scheduled to be released in January } 2019 \text {, Share Shima is an online matching service involving } \\
\text { food ingredients. It aims to provide a matching service for "food manufacturers and food } \\
\text { factories" handling food ingredients who "want to sell or want to buy" and to reduce food loss } \\
\text { at the distribution stage. }\end{array}$ \\
\hline & & $\begin{array}{l}\text { POCKETMARCHE is an app that enables direct purchases from farmers and fishermen. Sellers } \\
\text { are limited to farmers and fishermen, and the items are delivered directly to consumers. }\end{array}$ \\
\hline POCKETMARCHE & Pocket Marche, Inc. & $\begin{array}{l}\text { Consumers can interact directly with the producers. The app can reduce food loss in the early } \\
\text { stage by shortening the food chain period from production to distribution, and it also includes } \\
\text { awareness activities for reducing consumption stage food loss. }\end{array}$ \\
\hline
\end{tabular}


Table 2. Cont.

\begin{tabular}{lll}
\hline Name & Provider & Description \\
\hline
\end{tabular}

Group 2. Redistribution of surplus food

KURADASHI.jp Glaucks Co., Ltd.

KURADASHI.jp is a shopping site that supports various social contribution activities through its user purchasing activities. It is a social contribution food sharing platform. In addition to food, the company also sells unsold products at discounted prices. Users can choose to become a regular member or a premium member with a monthly fee of 540 yen.

Loss Zero is an e-commerce business that moves out-of-specification items and production surplus items from food manufacturers to consumers. A portion of its revenues is used to

Loss Zero Beautiful Smile Co., Ltd. provide education and employment support in Cambodia. According to the official website, the advantages to food manufacturers include "social contribution activities" and "awareness and image improvement." The website also states that the advantages to its users include the opportunities to "purchase products at a low price" and "contribute to society by eating." tabeloop is an e-commerce platform for buying and selling food that is to be discarded because it is out-of-specification or nearing the expiration date. According to the official website, a portion of the sale proceeds is donated worldwide to people suffering from hunger and poverty. It does not charge a membership registration fee or monthly fee, but it does charge sellers a $15 \%$ commission fee at the time of the transaction.

TABETE is an online platform that enables the purchase and sale of meals that are supposed to be discarded at restaurants. As of December 2018, 274 stores in Tokyo, 7 in Kanagawa, and

TABETE CoCooking Co., Ltd. 11 in Saitama were registered, and only the iOS version of the application has been released. The restaurants post unsold meals on the platform for each store. Then, users select from the discounted items and pick up the items at the restaurant. The company monetizes the service by taking a commission from the store-side.

Reduce GO is a service that allows users to receive food items that are likely to be unsold at nearby restaurants, stores, and retailers on a flat, monthly price basis. According to the official

Reduce GO SHIFFT Inc. website, as of December 2018, the monthly fee is 1980 yen, and users can order up to twice per month. Two per cent of the fee is donated to social activist organizations. As of December 2018, the company has 139 member stores.

Group 3. Restaurants that use waste and surplus ingredients

FOODPASPORT is a food sharing service platform that can be used once per day for a monthly fee of 2980 yen, providing a chef choice menu using surplus ingredients from restaurants. As of January 2019, the company has 337 member restaurants. Many of the restaurants have implemented a one-drink ordering system with an additional fee along with the monthly fee.

Group 4. Waste data management and utilization

Supply and

demand

optimization NEC Corporation

platform
This supply and demand optimization platform aims to solve food manufacturing, logistics, and sales value chain issues through demand forecasting using artificial intelligence (AI). According to the official website, the predicted numbers of customers, sales, and shipments can be provided through AI analyses to reduce food loss caused by a gap between the predicted and actual numbers.

Group 5. Extension of Food Expiration Date by Technology

DayBreak is a FoodTech venture company that utilizes a special refrigeration technology to extend food shelf life. The company also supports the domestic and overseas distribution of

DayBreak Daybreak Co., Ltd. food products using this special refrigeration technology and its network. Special rapid freezing refers to a freezing method where food quickly freezes after being subjected to temperatures ranging from $-1{ }^{\circ} \mathrm{C}$ to $-5^{\circ} \mathrm{C}$. It also includes freezing small ice crystals while maintaining their quality without destroying any cells.

Group 6. Discount and incentive businesses for loss reduction actions

"EcoBuy" is a system that reduces food loss using a smartphone app and provides points to consumers who purchase food with an approaching expiration date. Consumers (members) upload receipt images and information on shelf life and expiration date through the EcoBuy application to demonstrate that they purchased an EcoBuy target product. Then, the Point

EcoBuy NTT DoCoMo, Inc. Center confirms the details and awards the point to the consumer (member) if the conditions are satisfied. If they completely consume the target item, they receive a thank you message. If they receive the notification before they consume the item, they are encouraged to finish it by receiving a recipe that can be made from the purchased food items. According to a report prepared by the Tokyo Metropolitan Government, food loss was reduced by $31.2 \%$.

(Source: Created by the author based on the company websites in Japan.)

\section{New Business Proposal for Food Loss Reduction and Potential Survey Analysis}

\subsection{New Business Proposal for Food Loss reduction: "Canshoku" Service}

This study proposes a new food loss reduction service for restaurants called "Canshoku." The service corresponds to Group 6 in Tables 1 and 2 and provides coupons or points in digital applications if customers finish their meals at a restaurant; these points can be redeemed to avail discounts on their next meal. The points are awarded for images of 
their ordered food taken by consumers before and after their meals, and the points can be converted into restaurant coupons. Moreover, the proposal suggests a business model that allows restaurants to obtain users' eating and drinking data. These services also correspond to new services categorized in Groups 3 and 4 in Tables 1 and 2.

The term "Canshoku" is derived from the Japanese word "Kanshoku." Kanshoku is defined as "finishing every last bit of food served on the table." The word can be used worldwide, similar to how the word "mottainai" has been used. ("Mottainai" is a Japanese expression that has a colloquial English equivalent, "What a waste!" The term conveys a sense of regret over the waste. Nobel peace prize laureate Ms. Wangari Maathai introduced the term at a United Nations session as a slogan for environmental protection.) The reason to write "Kan" as "Can" in Roman letters is to reflect the meaning of "can" in English (a word which means "to be able to") and remain consistent with "Can + Shoku," which means "can (still) be consumed" for a business that aims to reduce food loss. "Canshoku" is involved with restaurants, users, various companies, food service providers, and Canshoku operating companies, and it uses an app to provide services to restaurant companies, individuals, and restaurant users. In this model, users utilize services in the following five steps:

1. User Canshoku app and point usage

Users can install the Canshoku app on their smartphones (Figure 1) and register as members. They can then enjoy the Canshoku service by logging in. They take pictures of their meals before eating at a restaurant. If they finish their meal, they take a picture after eating, enter the name of the restaurant and the dish, and send the pictures to the Canshoku operations department. If they do not finish the meal, they can select the reason for this, provide the name of the restaurant and dish, and send this information to the Canshoku operations department. The sent pictures demonstrate that the meal has been finished, which is scored by the operations department and converted into points. The pictures that are sent to illustrate that the meal was not completely eaten are converted into fewer points compared with those of the completed meal. This motivates the users to finish their meals next time. The users redeem the accumulated points for coupons and service rights and utilize the quick response code to spend them.

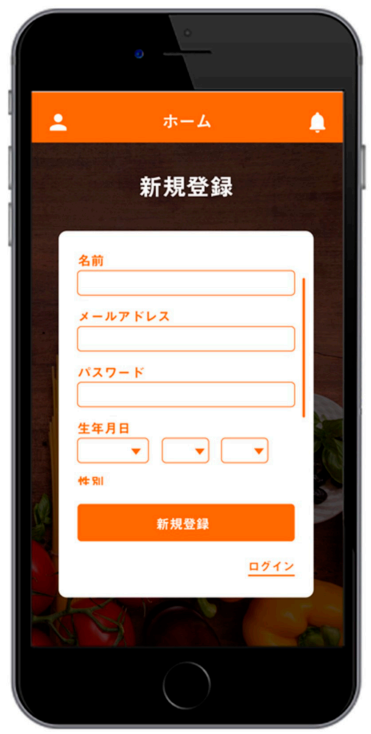

Home screen (new registration) in Japanese

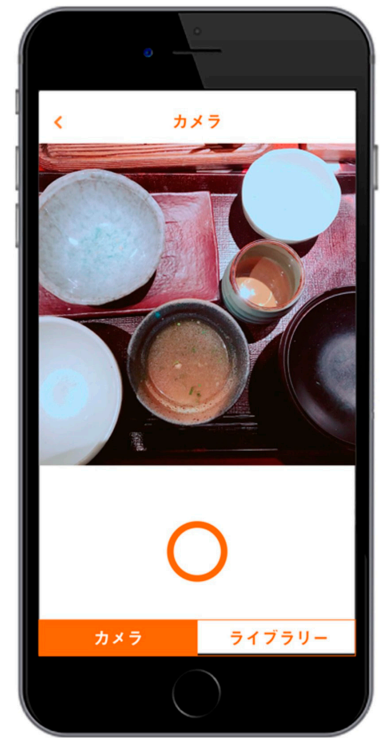

Camera screen (taking a picture after eating) in Japanese

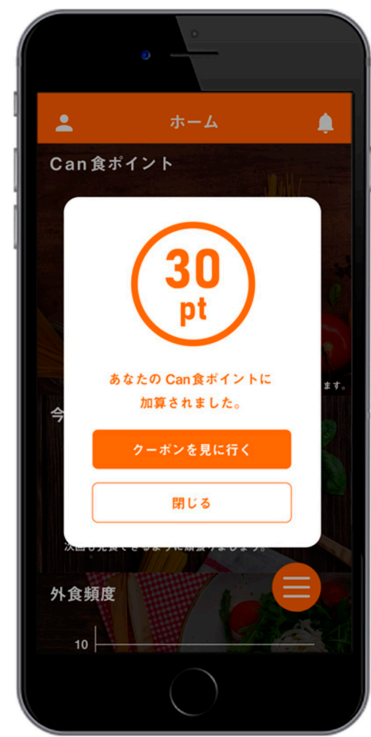

Point screen (providing points for coupons) in Japanese

Figure 1. Application images. 
Photographs can be taken up to three times per day, and the date and time the photo was taken are added to the picture as a function of the camera used in the app. This helps prevent fraudulent activities, such as reusing the same pictures. Twenty points are given when the meal completion rate is $100 \%$, and 10 points are given when the meal completion rate is $90 \%$. Pictures with any leftover food receive eight points. Based on this point reward system, the number of points necessary for redemption can be calculated, allowing users to redeem their points for a variety of items and services, such as restaurant coupons, thereby motivating them to earn more points and encouraging them to finish their meals.

2. Posting companies as point-exchange destinations

Providing company products and services to a point-exchange model business can be used to attract customers and promote sales. As described in Figure 1, it is assumed that posting a restaurant as a point-exchange destination can encourage visits to the restaurant. Profits are generated by a contingent fee, and no fee is incurred to post on point exchange as a destination. It is also assumed that profits are generated through the use of associated services, such as pick-up services, as a point-exchange destination.

3. Data use and sales

Canshoku collects information on who eats, when they eat, what type of food they eat, and how much they eat. Data are accumulated and used and can be sold to entities that demand marketing data on food, including major restaurants.

\section{Food support activities}

A portion of the Canshoku revenues is donated to organizations that operate cafeterias for children as a food source for poor children. From the meal completion perspective, this may simply be viewed as eating more. However, Canshoku emphasizes individual foodordering behaviors, such as recognizing their limits and avoiding leaving food uneaten. If consumers order meals with the intention to finish food items, food will only temporarily remain unsold at stores and markets. Connecting these situations to the social problem of food imbalances, this project combines efforts to help distribute surplus food found in markets to those who do not have enough with users who are not leaving their meals unfinished.

\subsection{Survey Data Collection and Summary}

To identify and analyze the consciousness and intention of people to use incentivesincluding the new business proposal in this study - to reduce food losses, necessary data were gathered via an online and smartphone survey in Japan. The Rakuten Insight was contacted to conduct the survey, and responses were collected between 22 and 27 November 2018. The questionnaire included objective questions based on gender, age, and income, and subjective questions to assess the respondents' awareness about the incentives to reduce food loss and their intention to use such incentives. Respondents were randomly selected by Rakuten Insight. To construct a sample without bias, Rakuten Insight distributed and gathered the questionnaires in proportion to the population of each prefecture in Japan by gender and age distribution. They contacted 66,636 individuals and obtained 7016 responses (response rate: 10.53\%). After excluding responses with incomplete answers, a final sample size of 5000 individuals (males: 2485, females: 2515) was obtained. We collected the data of individuals regarding gender $(M A L E)$, age $(A G E)$, household income $(H I N C)$, and education status (EDU) (see Table 3). Regarding the age distribution of the respondents, the numbers of respondents in their 20s or younger, in their 30s, 40s, 50s, 60s, and 70 s or older were 923 (18.5\%), 747 (14.9\%), $942(18.8 \%), 785(15.7 \%), 883(17.7 \%)$, and $720(14.4 \%)$, respectively. 
Table 3. Sample characteristics $(N=5000)$.

\begin{tabular}{|c|c|c|c|c|c|c|}
\hline Variable & Symbol & Definition & Mean & $\begin{array}{l}\text { Standard } \\
\text { Deviation }\end{array}$ & Min & Max \\
\hline Gender & $M A L E$ & $\begin{array}{l}\text { 1: if the individual is male; } 0 \text { : if the individual } \\
\text { is female. }\end{array}$ & 0.50 & 0.50 & 0 & 1 \\
\hline Age & $A G E$ & Current age (in years). & 48.57 & 16.30 & 15 & 79 \\
\hline \multirow{4}{*}{$\begin{array}{l}\text { Household } \\
\text { income } \\
(\text { reference: } \\
H_{\left.I N C_{0}\right)}\end{array}$} & $\mathrm{HINC}_{0}$ & $\begin{array}{l}\text { 1: if the household income of the individual } \\
\text { is }<5 \text { million yen; } 0 \text { : otherwise. }\end{array}$ & 0.39 & 0.49 & 0 & 1 \\
\hline & $H_{I N C}$ & $\begin{array}{l}\text { 1: if the household income of the individual } \\
\text { is } 5-10 \text { million yen; } 0 \text { : otherwise. }\end{array}$ & 0.32 & 0.47 & 0 & 1 \\
\hline & $\mathrm{HINC}_{2}$ & $\begin{array}{l}\text { 1: if the household income of the individual } \\
\text { is }>10 \text { million yen; } 0 \text { : otherwise. }\end{array}$ & 0.10 & 0.30 & 0 & 1 \\
\hline & $\mathrm{HINC}_{3}$ & $\begin{array}{l}\text { 1: if the household income of the individual } \\
\text { is unknown or not answered; } 0 \text { : otherwise. }\end{array}$ & 0.19 & 0.39 & 0 & 1 \\
\hline \multirow{6}{*}{$\begin{array}{l}\text { Education } \\
\text { status } \\
\text { (reference: } \\
\left.E D U_{0}\right)\end{array}$} & $E D U_{0}$ & $\begin{array}{l}\text { 1: if the individual is a high school graduate; } \\
0 \text { : otherwise. }\end{array}$ & 0.28 & 0.45 & 0 & 1 \\
\hline & $E D U_{1}$ & $\begin{array}{l}\text { 1: if the individual is a vocational school, } \\
\text { technical, or junior college graduate; } \\
0 \text { : otherwise. }\end{array}$ & 0.23 & 0.42 & 0 & 1 \\
\hline & $E D U_{2}$ & $\begin{array}{l}\text { 1: if the individual is a university student; } \\
0 \text { : otherwise. }\end{array}$ & 0.022 & 0.15 & 0 & 1 \\
\hline & $\mathrm{EDU}_{3}$ & $\begin{array}{l}\text { 1: if the individual has a bachelor's degree; } \\
0 \text { : otherwise. }\end{array}$ & 0.38 & 0.49 & 0 & 1 \\
\hline & $E D U_{4}$ & $\begin{array}{l}\text { 1: if the individual has a master's or } \\
\text { doctorate degree; } 0 \text { : otherwise. }\end{array}$ & 0.053 & 0.22 & 0 & 1 \\
\hline & $E D U_{5}$ & $\begin{array}{l}\text { 1: if the education status of the individual is } \\
\text { other or unknown; } 0 \text { : otherwise. }\end{array}$ & 0.036 & 0.19 & 0 & 1 \\
\hline
\end{tabular}

Notes: Symbols in the italics are used in analytical models.

Table 4 summarizes the definitions of the variables used in this study and their descriptive statistics. We also collected data on subjective items, including awareness about the incentives to reduce food loss and their intention to use these incentives. The subjective questionnaire items included three types of incentives to reduce food loss, individual's interests and experience of food sharing service (FSHA), maintenance of body weight (WEIG), interest in social contribution (SOCI), the individual's attitude toward leftover foods (LEFT), "mottainai" feeling for food loss (MOTT), and the individual's attitude behavior of appropriate ordering (ORDR).

The three types of incentives to ascertain the respondent's intention to use incentives to reduce food loss include the following:

1. If the restaurant provides a box (doggy bag) to bring back uneaten food, would you like to use it? $(1=$ no, $2=$ not very, $3=$ neutral, $4=$ somewhat yes, or $5=$ yes). $(D B A G)$

2. If you may choose a smaller amount of food and pay a cheaper price at a restaurant, do you think you will reduce the amount you order? $(1=$ no, $2=$ not very, $3=$ neutral, $4=$ somewhat yes, or $5=$ yes). (DISC)

3. If you finish your meal at a restaurant and get a coupon that will make your meal cheaper next time ("Canshoku" service), do you think you will be willing to finish it? ( $1=$ no, 2 = not very, 3 = neutral, $4=$ somewhat yes, or $5=$ yes $).(C A N S)$

The new business proposal "Canshoku" service can be compared to two similar incentive services to reduce food loss at the consumption stage by using these three variables. 
Table 4. Definitions of variables and descriptive statistics.

\begin{tabular}{|c|c|c|c|c|c|c|}
\hline Variable & Symbol & Definition & Mean & $\begin{array}{l}\text { Standard } \\
\text { Deviation }\end{array}$ & Min & Max \\
\hline \multirow{3}{*}{$\begin{array}{l}\text { Incentives to } \\
\text { reduce food loss }\end{array}$} & $D B A G$ & $\begin{array}{l}\text { If the restaurant provides a box (doggy bag) } \\
\text { to bring back uneaten food, would you like to } \\
\text { use it? (1: No, 2: Not very, 3: Neutral, } \\
\text { 4: Somewhat yes, or 5: Yes). }\end{array}$ & 3.87 & 1.24 & 1 & 5 \\
\hline & DISC & $\begin{array}{l}\text { If you may choose a smaller amount of food } \\
\text { and pay a cheaper price at a restaurant, do } \\
\text { you think you will reduce the amount you } \\
\text { order? (1: No, 2: Not very, 3: Neutral, } \\
\text { 4: Somewhat yes, or 5: Yes). }\end{array}$ & 3.86 & 1.21 & 1 & 5 \\
\hline & CANS & $\begin{array}{l}\text { If you finish your meal at a restaurant and get } \\
\text { a coupon or points that will make your meal } \\
\text { cheaper next time ("Canshoku" service), do } \\
\text { you think you will be willing to finish it? } \\
\text { (1: No, 2: Not very, 3: Neutral, } 4 \text { : Somewhat } \\
\text { yes, or } 5 \text { : Yes). }\end{array}$ & 3.83 & 1.24 & 1 & 5 \\
\hline \multirow{4}{*}{$\begin{array}{c}\text { Food share } \\
\left.\text { (reference: } F S H A_{0}\right)\end{array}$} & $F S H A_{0}$ & $\begin{array}{l}\text { 1: If an individual does not know and has no } \\
\text { interest in food sharing service which } \\
\text { provides surplus food to those who want it } \\
\text { for a fee (or free of charge); } 0 \text { : otherwise. }\end{array}$ & 0.66 & 0.47 & 0 & 1 \\
\hline & $F S H A_{1}$ & $\begin{array}{l}\text { 1: If an individual has used food sharing } \\
\text { service before but will no longer use it; } \\
0 \text { : otherwise. }\end{array}$ & 0.03 & 0.47 & 0 & 1 \\
\hline & $\mathrm{FSHA}_{2}$ & $\begin{array}{l}\text { 1: If an individual has used food sharing } \\
\text { service before and would like to continue } \\
\text { using it; } 0 \text { : otherwise. }\end{array}$ & 0.05 & 0.22 & 0 & 1 \\
\hline & $\mathrm{FSHA}_{3}$ & $\begin{array}{l}\text { 1: If an individual has never used the food } \\
\text { share service but would like to use it }\end{array}$ & 0.26 & 0.44 & 0 & 1 \\
\hline $\begin{array}{l}\text { Maintain weight } \\
\text { (Health) }\end{array}$ & WEIG & $\begin{array}{l}\text { Are you trying to maintain your proper } \\
\text { weight? (1: No, 2: Not very, 3: Neutral, } \\
\text { 4: Somewhat yes, or 5: Yes). }\end{array}$ & 3.52 & 1.16 & 1 & 5 \\
\hline $\begin{array}{l}\text { Interest in social } \\
\text { contribution } \\
\quad(\text { Social })\end{array}$ & SOCI & $\begin{array}{l}\text { The extent to which the individual has an } \\
\text { interest in social contribution (1: No, 2: Not } \\
\text { very, 3: Neutral, } 4 \text { : Somewhat yes, or 5: Yes). }\end{array}$ & 2.32 & 1.27 & 1 & 5 \\
\hline $\begin{array}{l}\text { Leftover foods } \\
\text { (Attitude) }\end{array}$ & LEFT & $\begin{array}{l}\text { Do you usually leave leftover food at } \\
\text { restaurants? (1: No, 2: Not very, 3: Neutral, } \\
\text { 4: Somewhat yes, or 5: Yes). }\end{array}$ & & & & \\
\hline $\begin{array}{c}\text { Mottainai } \\
\text { (subjective norm) }\end{array}$ & MOTT & $\begin{array}{l}\text { Do you feel wasteful (Mottainai) to leave } \\
\text { uneaten food? (1: No, 2: Not very, 3: Neutral, } \\
\text { 4: Somewhat yes, or 5: Yes). }\end{array}$ & 4.33 & 1.06 & 1 & 5 \\
\hline $\begin{array}{l}\text { Appropriate } \\
\text { ordering (perceived } \\
\text { behaviour control) }\end{array}$ & ORDR & $\begin{array}{l}\text { Are you usually conscious of ordering the } \\
\text { amount you can eat at a restaurant? (1: No, } \\
\text { 2: Not very, 3: Neutral, } 4 \text { : Somewhat yes, or } \\
\text { 5: Yes). }\end{array}$ & & & & \\
\hline
\end{tabular}

Notes: Symbols in the italics are used in analytical models.

Table 4 shows that the means of variables of the intention of using three services to reduce food loss $(D B A G, D I S C$, and $C A N S)$ are $3.87,3.86$, and 3.83, respectively, indicating that the intention of using such services is high. The means of variables of MOTT are also high (4.33), while more than half of the individuals are not aware or do not show interest in food sharing services that provide surplus food to those who want it for a fee (or free of charge) (the means of $F S H A_{0}$ is 0.66 ).

\subsection{Analysis and Results}

Based on existing analytical models such as consumer models and sharing service models, this study analyzes the feasibility, future potential, and effect of our newly proposed 
service by assessing consumers' awareness of incentives and food loss via online and smartphone surveys. We integrated and extended the existing models for our analysis, as shown in Figure 2.

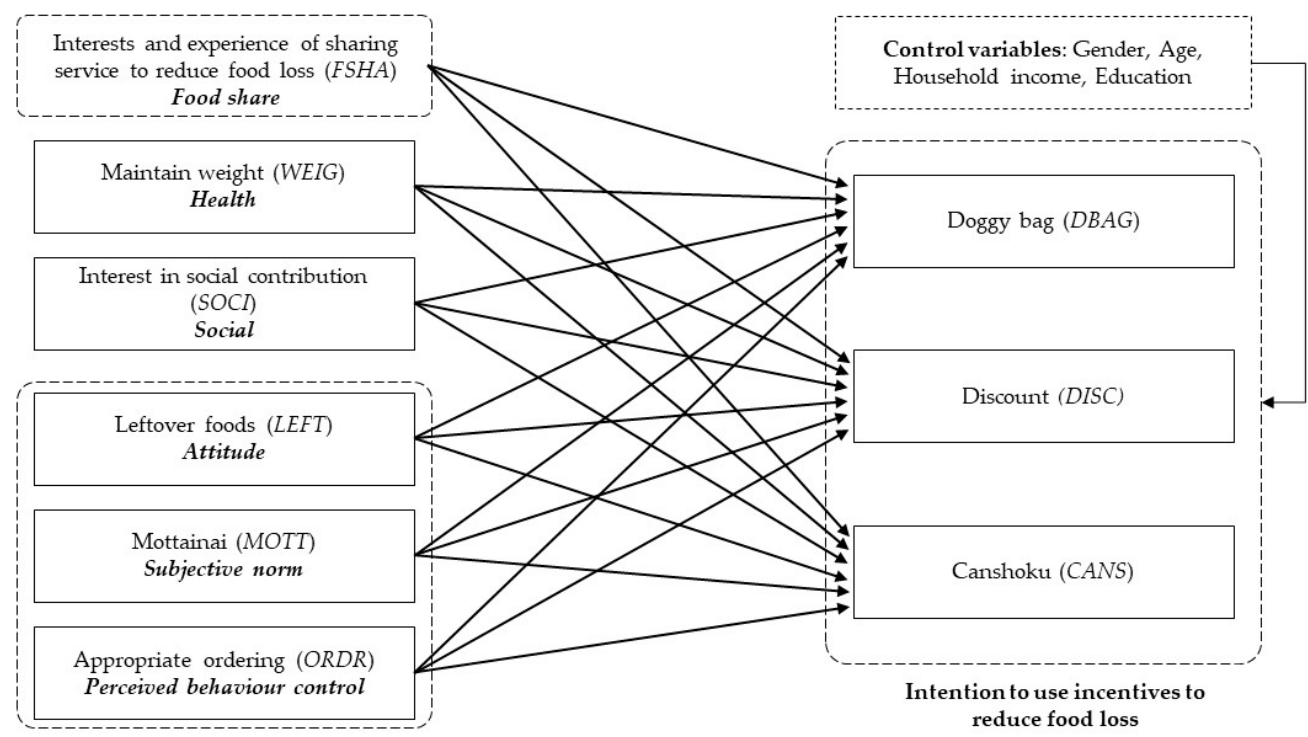

Figure 2. Analytical model concept.

We consider three models of intention to use incentives to reduce food loss using ordered logit models and compare the new business proposed in this study to two similar incentive services. In the models, the variables of intention to use three services $(D B A G$, DISC, and CANS) to reduce food loss are used as objective variables, and the other variables shown in Tables 3 and 4 are the control and explanatory variables, respectively.

We use the variables of gender $(M A L E)$, age (AGE), household income (HINC), and education status $(E D U)$ as control variables. The existing literature suggests that these demographic factors are associated with food wastage reduction intentions [55,61]. We also use the variables of individual's interests and experience of food sharing service $(F S H A)$, maintenance of body weight (WEIG), interest in social contribution (SOCI), the individual's attitude for leftover foods (LEFT), "mottainai" feeling for food loss (MOTT), and the individual's attitude behavior of appropriate ordering (ORDR) as an important factor of sharing service, health, social, attitude, subjective norm, and perceived behavior control, respectively, in reference to existing basic models. Table 5 presents the results of the correlations between explanatory variables. Although several subjective variables were used in this model, the correlations between the variables were low.

Table 5. Correlation of the explanatory variables.

\begin{tabular}{|c|c|c|c|c|c|c|c|c|}
\hline & $F S H A_{1}$ & $\mathrm{FSHA}_{2}$ & $\mathrm{FSHA}_{3}$ & WEIG & SOCI & $L E F T$ & MOTT & ORDR \\
\hline$F S H A_{1}$ & 1.00 & & & & & & & \\
\hline $\mathrm{FSHA}_{2}$ & -0.039 & 1.00 & & & & & & \\
\hline $\mathrm{FSHA}_{3}$ & -0.096 & -0.14 & 1.00 & & & & & \\
\hline WEIG & -0.0036 & -0.028 & 0.11 & 1.00 & & & & \\
\hline SOCI & 0.043 & 0.0073 & 0.33 & 0.14 & 1.00 & & & \\
\hline LEFT & 0.042 & 0.020 & -0.080 & 0.028 & -0.038 & 1.00 & & \\
\hline MOTT & -0.083 & -0.050 & 0.12 & 0.25 & 0.077 & -0.17 & 1.00 & \\
\hline ORDR & -0.053 & -0.041 & 0.13 & 0.35 & 0.11 & -0.075 & 0.39 & 1.00 \\
\hline
\end{tabular}

Notes: FSHA indicates the variable regarding the experience of food sharing service; WEIG indicates the variable regarding maintenance of body weight; $S O C I$ indicates the variable regarding interest in social contribution; LEFT indicates the variable regarding the individual's attitude toward leftover foods; MOTT indicates the variable regarding "mottainai" feeling for food loss; ORDR indicates the variable regarding the individual's attitude behavior of appropriate ordering, respectively. 
Table 6 presents the results of ordered logit regression. As indicated in Table 6, the coefficients of the gender (male) variable are significantly negative for DBAG and DISC models, indicating that males are less likely to use a box (doggy bag) to bring back uneaten food $(D B A G)$, choose smaller amounts of food, and pay cheaper prices at restaurants (DISC). The coefficients of the age variable are not significant for DBAG, but are significantly positive for DISC and significantly negative for CANS, indicating that older individuals tend to choose a smaller amount of food and pay a cheaper price at restaurants (DISC), and younger individuals tend to use "Canshoku" service (CANS).

Regarding household income variables, the reference is $H I N C_{0}$ (1: if the household income of the individual is $<5$ million yen; 0: otherwise). Significantly negative effects of all HINC variables are observed for $D B A G$, indicating that individuals with higher household income are less likely to use a box (doggy bag) to bring back uneaten food $(D B A G)$ compared to individuals whose household income is $<5$ million yen. While no significant effects of the variables of household income on the DISC model are observed, in the CANS model, the coefficient of the $H_{I N C_{1}}$ variable is significantly positive and the coefficient of the $\mathrm{HINC}_{3}$ variable is significantly negative. These results show that only individuals whose household income is 5 to 10 million yen $\left(H I N C_{1}\right)$ are more likely to use the "Canshoku" service.

Regarding education status variables, the reference is $E D U_{0}(1$ : if the individual is a high school graduate; 0: otherwise). While no significant effects of the variables of education status on the DISC model are observed, in the CANS model, the coefficients of the $E D U_{3}$ and $E D U_{4}$ variables are significantly negative, showing that individuals with a bachelor's, master's, or doctorate degree are less likely to use the "Canshoku" service.

The coefficients of variables regarding the mottainai feeling for unfinished food (MOTT) and the individual's attitude behavior of appropriate ordering (ORDR) are significantly positive for all models. In contrast, the variable of interest in social contribution (SOCI) is not significant only in the DISC model and the variable of interest of inexperienced individuals in sharing food $\left(\mathrm{FSHA}_{3}\right)$, maintaining proper weight (WEIG), and the individual's attitude toward leftover foods (LEFT) is not significant only in the CANS model. This indicates that the individual's mottainai feeling for unfinished food and behavior of appropriate ordering are positively associated with the intention to use the three incentive services to reduce food loss; however, only the DISC service is not significantly associated with the interest of respondents regarding social contribution, although such services lead to a social reduction in food loss. Moreover, we find that only the "Canshoku" (CANS) service is not significantly associated with the interest of service-inexperienced individuals in sharing food, maintaining weight, and attitude for leftover foods.

These results also indicate that although the proposed "Canshoku" service is similar to approaches that provide a box (doggy bag) to bring back uneaten food or provide discounts for smaller amounts of food in a restaurant, there is a difference in the characteristics of potential users of this service. Such new application services can be used by younger age groups and people with slightly higher household incomes than the other two services. 
Table 6. Estimation results of the three models.

\begin{tabular}{|c|c|c|c|}
\hline Variables & (1) $D B A G$ & (2) DISC & (3) $C A N S$ \\
\hline MALE & $\begin{array}{c}-0.56^{* * *} \\
(0.058)\end{array}$ & $\begin{array}{c}-0.54^{* * *} \\
(0.058)\end{array}$ & $\begin{array}{r}-0.025 \\
(0.058)\end{array}$ \\
\hline$A G E$ & $\begin{array}{l}-0.0013 \\
(0.0018)\end{array}$ & $\begin{array}{l}0.0035^{*} \\
(0.0018)\end{array}$ & $\begin{array}{c}-0.023^{* * *} \\
(0.0018)\end{array}$ \\
\hline $\mathrm{HINC}_{1}$ & $\begin{array}{l}-0.12 * \\
(0.066)\end{array}$ & $\begin{array}{c}0.078 \\
(0.066)\end{array}$ & $\begin{array}{l}0.16^{* *} \\
(0.066)\end{array}$ \\
\hline $\mathrm{HINC}_{2}$ & $\begin{array}{c}-0.26^{* * *} \\
(0.096)\end{array}$ & $\begin{array}{l}-0.12 \\
(0.096)\end{array}$ & $\begin{array}{c}-0.093 \\
(0.096)\end{array}$ \\
\hline $\mathrm{HINC}_{3}$ & $\begin{array}{c}-0.21^{* * *} \\
(0.075)\end{array}$ & $\begin{array}{c}0.038 \\
(0.075)\end{array}$ & $\begin{array}{c}-0.17^{* *} \\
(0.074)\end{array}$ \\
\hline$E D U_{1}$ & $\begin{array}{l}0.16^{* *} \\
(0.077)\end{array}$ & $\begin{array}{c}-0.044 \\
(0.077)\end{array}$ & $\begin{array}{c}-0.10 \\
(0.076)\end{array}$ \\
\hline$E D U_{2}$ & $\begin{array}{c}-0.025 \\
(0.20)\end{array}$ & $\begin{array}{l}-0.26 \\
(0.20)\end{array}$ & $\begin{array}{l}-0.23 \\
(0.20)\end{array}$ \\
\hline $\mathrm{EDU}_{3}$ & $\begin{array}{l}-0.087 \\
(0.070)\end{array}$ & $\begin{array}{c}0.041 \\
(0.070)\end{array}$ & $\begin{array}{c}-0.21^{* * *} \\
(0.069)\end{array}$ \\
\hline$E D U_{4}$ & $\begin{array}{l}-0.13 \\
(0.13)\end{array}$ & $\begin{array}{c}-0.0048 \\
(0.13)\end{array}$ & $\begin{array}{c}-0.24^{*} \\
(0.13)\end{array}$ \\
\hline$E D U_{5}$ & $\begin{array}{l}-0.18 \\
(0.15)\end{array}$ & $\begin{array}{c}-0.085 \\
(0.15)\end{array}$ & $\begin{array}{l}-0.18 \\
(0.15)\end{array}$ \\
\hline$F S H A_{1}$ & $\begin{array}{c}-0.032 \\
(0.17)\end{array}$ & $\begin{array}{c}0.18 \\
(0.17)\end{array}$ & $\begin{array}{c}-0.083 \\
(0.17)\end{array}$ \\
\hline$F S H A_{2}$ & $\begin{array}{l}0.096 \\
(0.12)\end{array}$ & $\begin{array}{c}0.14 \\
(0.12)\end{array}$ & $\begin{array}{l}0.041 \\
(0.12)\end{array}$ \\
\hline $\mathrm{FSHA}_{3}$ & $\begin{array}{c}0.55^{* * *} \\
(0.070)\end{array}$ & $\begin{array}{l}0.34^{* * *} \\
(0.069)\end{array}$ & $\begin{array}{c}0.11 \\
(0.069)\end{array}$ \\
\hline WEIG & $\begin{array}{c}0.070 * * * \\
(0.027)\end{array}$ & $\begin{array}{l}0.24^{* * *} \\
(0.027)\end{array}$ & $\begin{array}{c}0.029 \\
(0.027)\end{array}$ \\
\hline SOCI & $\begin{array}{c}0.082^{* * * *} \\
(0.024)\end{array}$ & $\begin{array}{c}0.031 \\
(0.024)\end{array}$ & $\begin{array}{c}0.073^{* * *} \\
(0.023)\end{array}$ \\
\hline LEFT & $\begin{array}{l}0.11^{* * *} \\
(0.023)\end{array}$ & $\begin{array}{l}0.22^{* * *} \\
(0.024)\end{array}$ & $\begin{array}{l}-0.030 \\
(0.023)\end{array}$ \\
\hline MOTT & $\begin{array}{l}0.95^{* * *} \\
(0.032)\end{array}$ & $\begin{array}{l}0.74^{* * *} \\
(0.031)\end{array}$ & $\begin{array}{l}0.87^{* * *} \\
(0.032)\end{array}$ \\
\hline ORDR & $\begin{array}{l}0.16^{* * *} \\
(0.027)\end{array}$ & $\begin{array}{l}0.33^{* * *} \\
(0.028)\end{array}$ & $\begin{array}{l}0.20^{* * *} \\
(0.027)\end{array}$ \\
\hline /cut1 & $\begin{array}{c}1.86^{* * *} \\
(0.19)\end{array}$ & $\begin{array}{c}2.53^{* * *} \\
(0.19)\end{array}$ & $\begin{array}{l}0.35 * \\
(0.19)\end{array}$ \\
\hline /cut2 & $\begin{array}{c}2.68^{* * *} \\
(0.19)\end{array}$ & $\begin{array}{c}3.35^{* * *} \\
(0.19)\end{array}$ & $\begin{array}{c}1.17^{* * *} \\
(0.19)\end{array}$ \\
\hline /cut3 & $\begin{array}{c}4.21 * * * \\
(0.20)\end{array}$ & $\begin{array}{c}5.00 * * * \\
(0.20)\end{array}$ & $\begin{array}{c}2.91 * * * \\
(0.19)\end{array}$ \\
\hline /cut4 & $\begin{array}{c}5.55^{* * *} \\
(0.20)\end{array}$ & $\begin{array}{c}6.30^{* * *} \\
(0.21)\end{array}$ & $\begin{array}{c}3.94^{* * *} \\
(0.19)\end{array}$ \\
\hline Observations & 5000 & 5000 & 5000 \\
\hline Log likelihood & -6075.43 & -6125.67 & -6212.43 \\
\hline LR statistics & 1820.59 & 1691.82 & 1520.88 \\
\hline Pseudo R2 & 0.13 & 0.12 & 0.11 \\
\hline
\end{tabular}

\section{Conclusions}

This study has theoretical and practical implications regarding the reduction in food loss and wastage. We proposed new business strategies after comprehensively investigating global food loss reduction initiatives and strategies to address the remaining challenges of the existing business models. For instance, although concerns about food losses and food sharing services have risen recently in Japan, studies on practical interventions to prevent 
food wastage and business models that can reduce food losses and wastage at restaurants are lacking. In addition, a limited number of people use sharing economy services in Japan.

Previous research indicated analytical frameworks or models of users' motivation, such as consumer theory, to reduce food losses or to use sharing services separately. However, the integrated evaluation of consumer theory, food wastage behavior in restaurants, perception of doggy bags, and new sharing business applications is important; existing studies concerning food loss and wastage have not focused on the intersection of these issues in the analytic model. Therefore, in this study, we analyzed the feasibility, future potential, and effect of our model by assessing consumer awareness of incentives and food loss by referencing the proposed new business incentive model to reduce food loss, particularly in restaurants. As there were no data on the above-mentioned aspects of people's perception, we collected data via online and smartphone surveys and analyzed the characteristics of potential user intentions to utilize the service in comparison with other similar services.

We integrated and extended the analytical framework based on existing analytical models, such as consumer models and sharing service models, to analyze the feasibility, future potential, and effect of this newly proposed service. For instance, we analyzed variables related to social, health, and food share service factors, in addition to variables of attitude, subjective norm, and perceived behavior control.

The results of the analysis showed that the services that provide incentives to reduce the instances of unfinished meals at a restaurant, except the proposed "Canshoku" service, are likely to be used by people who have interests in using food sharing services but are not experienced in the services, those who try to maintain proper body weight, and those who have an attitude to discard leftover foods. This means that although the proposed "Canshoku" service is similar to the other two approaches, there is a difference in the characteristics of potential users of the "Canshoku" service.

Our findings also contribute to the existing body of relevant knowledge and could be applied in practice more effectively. For instance, we find that the proposed new service, which uses digital and mobile applications, has the potential to be used by younger people and people with household incomes ranging from 5 to 10 million yen. This suggests that such services have the potential to create new target groups to reduce food loss. These target groups have not always been covered by the existing businesses. Moreover, the proposed service has the potential to develop into new businesses in the future. For instance, the service allows restaurants to obtain user eating and drinking data, which can be used to attract more customers through the point conversion system. Providing points when a customer finishes eating a meal at a restaurant without wasting food will not only make the next meal cheaper but will also be used as an incentive to engage in social contributing activities by using the points.

This study not only has academic contributions but also provides practical information and implications for other incentive measures and practices for reducing food wastage in both developing and developed economies. However, this study is limited in terms of actual behaviors in our model. We realize that even though users' intentions to use incentive services to reduce food loss have been examined in this study, the actual applicability or behavior of such services and prediction of actual user behavior are not yet understood because there are limited businesses, and those that do exist are not recognized, especially in Japan. Thus, further research and case studies similar to this that could explore other cities or countries other than Japan are required.

Author Contributions: Conceptualization, J.I. and H.N.; methodology, J.I. and H.N.; software, J.I. and H.N.; validation, J.I. and H.N.; formal analysis, J.I. and H.N.; investigation, J.I. and H.N.; resources, H.N.; data curation, J.I. and H.N.; writing-original draft preparation, J.I. and H.N.; writingreview and editing, H.N.; visualization, J.I. and H.N.; supervision, H.N.; project administration, H.N.; funding acquisition, H.N. All authors have read and agreed to the published version of the manuscript. 
Funding: This work was supported by the Japan Society for the Promotion of Science under a Grant-in-Aid for Early-Career Scientists (B) (19K13808).

Institutional Review Board Statement: Not applicable.

Informed Consent Statement: Informed consent was obtained from all subjects involved in the study.

Data Availability Statement: Not applicable.

Conflicts of Interest: The authors declare no conflict of interest.

\section{References}

1. FUSIONS. FUSIONS Definitional Framework for Food Wastage; Full Report; European Commission: Brussels, Belgium, 2014. Available online: https://www.eu-fusions.org/phocadownload/Publications/FUSIONS\%20Definitional\%20Framework\%20 for\%20Food\%20Waste\%202014.pdf (accessed on 26 August 2020).

2. Food and Agriculture Organization (FAO). Global Food Losses and Food Wastage: Extent, Causes, and Prevention; Food and Agriculture Organization of the United Nations: Rome, Italy, 2011.

3. Koester, U.; Loy, J.P.; Ren, Y. Food loss and waste: Some guidance. EuroChoices 2020, 19, 17-21. [CrossRef]

4. Gustavsson, J.; Cederberg, C.; Sonesson, U.; Emanuelsson, A. The Methodology of the FAO Study: Global Food Losses and Food Wastage-Extent, Causes and Prevention. Available online: https://pdfs.semanticscholar.org/19c0/065b1ad3f83f5ce7b0b16742 d137d0f2125e.pdf?_ga=2.19958584.1621569287.1598411203-236262360.1597364484 (accessed on 26 August 2020).

5. Neff, R.A.; Spiker, M.L.; Truant, P.L. Wasted food: U.S. consumers' reported awareness, attitudes, and behaviors. PLoS ONE 2015, 10, e0127881. [CrossRef] [PubMed]

6. Qi, D.; Roe, B.E. Household food wastage: Multivariate regression and principal component analyses of awareness and attitudes among U.S. consumers. PLoS ONE 2016, 11, e0159250. [CrossRef] [PubMed]

7. Eriksson, M.; Osowski, C.P.; Björkman, J.; Hansson, E.; Malefors, C.; Eriksson, E.; Ghosh, R. Tree structure: A general framework for food wastage quantification in food services. Resour. Conserv. Recycl. 2018, 130, 140-151. [CrossRef]

8. Eriksson, M.; Lindgren, S.; Osowski, C.P. Mapping of food wastage quantification methodologies in the food services of Swedish municipalities. Resour. Conserv. Recycl. 2018, 137, 191-199. [CrossRef]

9. Eriksson, M.; Malefors, C.; Bergström, P.; Eriksson, E.; Persson Osowski, C. Quantities and quantification methodologies of food wastage in Swedish hospitals. Sustainability 2020, 12, 3116. [CrossRef]

10. Capps, O.; Ishdorj, A.; Murano, P.S.; Field, L.; Hutto, A.; Storey, M. Waste Not Want Not. Choices 2019, 34, 1-8.

11. Morone, P.; Falcone, P.M.; Imbert, E.; Morone, A. Does food sharing lead to food wastage reduction? An experimental analysis to assess the challenges and opportunities of a new consumption model. J. Clean. Prod. 2018, 185, 749-760. [CrossRef]

12. Schanes, K.; Stagl, S. Food wastage Fighters: What motivates people to engage in food sharing? J. Clean. Prod. 2019, $211,1491-1501$. [CrossRef]

13. Richards, T.J.; Hamilton, S.F. Food wastage in the sharing economy. Food Policy 2018, 75, 109-123. [CrossRef]

14. Nakamura, H.; Abe, N.; Mizunoya, T. Factors inhibiting the use of sharing economy services in Japan. J. Clean. Prod. 2021, 278, 123981. [CrossRef]

15. Silvennoinen, K.; Heikkilä, L.; Katajajuuri, J.M.; Reinikainen, A. Food wastage volume and origin: Case studies in the Finnish food service sector. Waste Manag. 2015, 46, 140-145. [CrossRef] [PubMed]

16. Thyberg, K.L.; Tonjes, D.J. Drivers of food wastage and their implications for sustainable policy development. Resour. Conserv. Recycl. 2016, 106, 110-123. [CrossRef]

17. Eriksson, M.; Osowski, C.P.; Malefors, C.; Björkman, J.; Eriksson, E. Quantification of food wastage in public catering services-A case study from a Swedish municipality. Waste Manag. 2017, 61, 415-422. [CrossRef]

18. Muth, M.K.; Birney, C.; Cuéllar, A.; Finn, S.M.; Freeman, M.; Galloway, J.N.; Meyer, E. A systems approach to assessing the environmental and economic effects of food loss and waste interventions in the United States. Sci. Total Environ. 2019, 685, 1240-1254. [CrossRef] [PubMed]

19. Stöckli, S.; Niklaus, E.; Dorn, M. Call for testing interventions to prevent consumer food wastage. Resour. Conserv. Recycl. 2018, 136, 445-462. [CrossRef]

20. Yamada, T.; Asari, M.; Miura, T.; Niijima, T.; Yano, J.; Sakai, S. Municipal solid waste composition and food loss reduction in Kyoto City. J. Mater. Cycles Waste Manag. 2017, 19, 1351-1360. [CrossRef]

21. Belk, R. You are what you can access: Sharing and collaborative consumption online. J. Bus. Res. 2014, 67, 1595-1600. [CrossRef]

22. Böcker, L.; Meelen, T. Sharing for people, planet, or profit? Analyzing motivations for participation in the intended sharing economy. Environ. Innov. Soc. Transit. 2017, 23, 28-39.

23. Botsman, R.; Rogers, R. What's Mine is Yours: How Collaborative Consumption is Changing the Way We Live; Collins: London, UK, 2011.

24. Cheng, M. Sharing economy: A review and agenda for future research. Int. J. Hosp. Manag. 2016, 57, 60-70. [CrossRef]

25. Lindblom, A.; Lindblom, T.; Wechtler, H. Collaborative consumption as C2C trading: Analyzing the effects of materialism and price consciousness. J. Retail. Consum. Serv. 2018, 44, 244-252. [CrossRef] 
26. Möhlmann, M. Collaborative consumption: Determinants of satisfaction and the likelihood of using a sharing economy option again. J. Consum. Behav. 2015, 14, 193-207. [CrossRef]

27. Nakamura, H.; Abe, N. The role of a non-profit organization-run public bicycle-sharing programme: The case of Kitakyushu City, Japan. J. Transp. Geogr. 2014, 41, 338-345. [CrossRef]

28. Nakamura, H.; Abe, N. Evaluation of the hybrid model of public bicycle-sharing operation and private bicycle parking management. Transp. Policy 2014, 35, 31-41. [CrossRef]

29. Nakamura, H.; Abe, N. Tourist decisions in renting various personal travel modes: A case study in Kitakyushu City, Japan. Tour. Manag. 2016, 55, 85-93. [CrossRef]

30. Nakamura, H.; Uchida, A.; Managi, S. Relationship between community sharing of new personal transportation and local residents' daily life consciousness. Econ. Anal. Policy 2019, 61, 104-110. [CrossRef]

31. Narasimhan, C.; Papatla, P.; Jiang, B.; Kopalle, P.; Messinger, P.; Moorthy, S.; Proserpio, D.; Subramanian, U.; Wu, C.; Zhu, T. Sharing Economy: Review of Current Research and Future Directions. Cust. Needs Solut. 2018, 5, 93-106. [CrossRef]

32. Geissinger, A.; Laurell, C.; Öberg, C.; Sandström, C. How sustainable is the sharing economy? Sustainability connotations of sharing economy platforms. J. Clean. Prod. 2019, 206, 419-429. [CrossRef]

33. Heinrichs, H. Sharing economy: A potential new pathway to sustainability. GAIA-Ecol. Perspect. Sci. Soc. 2016, 22, 228-231. [CrossRef]

34. Davies, A.; David, E. Geoforum urban food sharing: Emerging geographies of production, consumption, and exchange. Geoforum 2019, 99, 154-159. [CrossRef]

35. Farr-Wharton, G.; Foth, M.; Choi, J.H.J. Identifying factors that promote consumer behaviors causing expired domestic food wastage. J. Consum. Behav. 2014, 13, 393-402. [CrossRef]

36. Michelini, L.; Principato, L.; Iasevoli, G. Understanding food-sharing models to tackle sustainability challenges. Ecol. Econ. 2018, 145, 205-217. [CrossRef]

37. Barnes, S.J.; Mattsson, J. Understanding current and future issues in collaborative consumption: A four-stage Delphi study. Technol. Forecast. Soc. Change 2016, 104, 200-211. [CrossRef]

38. Ozanne, L.K.; Ballantine, P.W. Sharing as a form of anti-consumption? Examination of toy library users. J. Consum. Behav. 2010, 9 , 485-498. [CrossRef]

39. Gössling, S.; Hall, C.M. Sharing versus collaborative economy: How to align ICT developments and the SDGs in tourism? J. Sustain. Tour. 2019, 27, 74-96. [CrossRef]

40. O'Rourke, D.; Lollo, N. Transforming consumption: From decoupling to behavior change, to system changes for sustainable consumption. Annu. Rev. Environ. Resour. 2015, 40, 233-259. [CrossRef]

41. Acquier, A.; Daudigeos, T.; Pinkse, J. Promises and Paradoxes of the sharing economy: An organizing framework. Technol. Forecast. Soc. Change 2017, 125, 1-10. [CrossRef]

42. Mair, J.; Reischauer, G. Capturing the dynamics of the sharing economy: Institutional research on the plural forms and practices of sharing economy organizations. Technol. Forecast. Soc. Change 2017, 125, 11-20. [CrossRef]

43. Hamari, J.; Sjöklint, M.; Ukkonen, A. The sharing economy: Why do people participate in collaborative consumption? Am. Soc. Info. Sci. Technol. 2015, 67, 2047-2059. [CrossRef]

44. Hawlitschek, F.; Teubner, T.; Gimpel, H. Consumer motives for peer-to-peer sharing. J. Clean. Prod. 2018, 204, 144-157. [CrossRef]

45. Makov, T.; Shepon, A.; Krones, J.; Gupta, C.; Chertow, M. Social and environmental analysis of food wastage abatement via the peer-to-peer sharing economy. Nat. Commun. 2020, 11, 1156. [CrossRef] [PubMed]

46. Stancu, V.; Haugaard, P.; Lahteenmaki, L. Determinants of consumer food wastage behavior: Two routes to food wastage. J. Appet. 2016, 96, 7-17. [CrossRef] [PubMed]

47. Soorani, F.; Ahmadvand, M. Determinants of consumers' food management behavior: Applying and extending the theory of planned behavior. Waste Manag. 2019, 98, 151-159. [CrossRef] [PubMed]

48. Ajzen, I. Theory of planned behavior. Organ. Behav. Hum. Decis. Processes 1991, 50, 179-211. [CrossRef]

49. Ajzen, I. Perceived behavioral control, self-efficacy, locus of control, and the theory of planned behavior 1. J. Appl. Soc. Psychol. 2002, 32, 665-683. [CrossRef]

50. Ajzen, I. Consumer attitudes and behavior: The theory of planned behavior applied to food consumption decisions. Riv. Econ. Agrar./Italian Rev. Agric. Econ. 2015, 70, 121-138.

51. Stefan, V.; van Herpen, E.; Tudoran, A.A.; Lähteenmäki, L. Avoiding food wastage by Romanian consumers: The importance of planning and shopping routines. Food Qual. Prefer. 2013, 28, 375-381. [CrossRef]

52. Visschers, V.H.; Wickli, N.; Siegrist, M. Sorting out food wastage behavior: A survey on the motivators and barriers of self-reported amounts of food wastage in households. J. Environ. Psychol. 2016, 45, 66-78. [CrossRef]

53. Russell, S.V.; Young, C.W.; Unsworth, K.L.; Robinson, C. Bringing habits and emotions into food wastage behavior. Resour. Conserv. Recycl. 2017, 125, 107-114. [CrossRef]

54. Barone, A.M.; Grappi, S.; Romani, S. "The road to food wastage is paved with good intentions": When Consumers' goals inhibit the minimization of household food wastage. Resour. Conserv. Recycl. 2019, 149, 97-105. [CrossRef]

55. Attiq, S.; Danish, M.; Kaur, P.; Junaid, M.; Hasni, S.; Dhir, A. Drivers of food wastage reduction behavior in the household context. Food Qual. Prefer. 2021, 94, 104300. [CrossRef] 
56. Filimonau, V.; Matute, J.; Kubal-Czerwińska, M.; Krzesiwo, K.; Mika, M. The determinants of consumer engagement in restaurant food wastage mitigation in Poland: An exploratory study. J. Clean. Prod. 2020, 247, 119105. [CrossRef]

57. Coşkun, A.; Özbük, R.M.Y. What influences consumers' food wastage behavior in restaurants? Application of extended theory of planned behavior. Waste Manag. 2020, 117, 170-178. [CrossRef] [PubMed]

58. Van Herpen, E.; De Hooge, I.E.; de Visser-Amundson, A.; Kleijnen, M.P. Take it or leave it: How an opt-out strategy for doggy bags affects consumer food wastage behavior and restaurant evaluations? J. Clean. Prod. 2021, 325, 129199. [CrossRef]

59. Dhir, A.; Talwar, S.; Kaur, P.; Malibari, A. Food wastage in hospitality and food services: A systematic literature review and framework development approach. J. Clean. Prod. 2020, 270, 122861. [CrossRef]

60. Sato, M.; Hatta, K.; Higuchi, W.; Hayashida, T.; Hotta, K.; Wunderlich, S.M. Efforts to reduce food loss in restaurants and to assess consumer awareness in Japan. WIT Trans. Ecol. Environ. Environ. Impact V 2020, 245, 21-30.

61. Heidari, A.; Mirzaii, F.; Rahnama, M.; Alidoost, F. A theoretical framework for explaining the determinants of food wastage reduction in residential households: A case study of Mashhad, Iran. Environ. Sci. Pollut. Res. 2019, 27, 6774-6784. [CrossRef] 